\title{
Optimization of Crude Oil Transfer by Trucking Services with Agent Based Modelling
}

\author{
Nurma Amelia, Ferliadi F, Avid Christa, Fergyanto E Gunawan, Muhammad Asrol \\ Industrial Engineering Department, BINUS Graduate Program - Master of Industrial Engineering, \\ Bina Nusantara University, Jakarta, 11480, Indonesia
}

\begin{abstract}
Transportation and distributions network hold an important role to maintain business stability in oil and gas industry. In this work, the simulation modelling to optimize the transportation is proposed for the oil and gas company. An agent-based modelling is developed to find the optimal solutions. Two route alternatives of the transportation were found as the constraint of the model. The result showed that the simulations model enabled to find the number of the truck to operate as the optimal transportation solution. The simulation model demonstrated that the route 2 provided the optimal solution in minimizing transportation cost and maximized the number of distributed crude oil.
\end{abstract}

Keywords - agent based, transportation, trucking, production.

\section{Introduction}

In recent years, oil and gas prices have experienced drastic and fluctuating changes in the global and Indonesian markets. At present, oil prices fluctuate in the range of 20-70 USD / barrel [1].

DOI: 10.18421/TEM103-53

https://doi.org/10.18421/TEM103-53

Corresponding author: Nurma Amelia,

Industrial Engineering Department, BINUS Graduate Program - Master of Industrial Engineering, Bina Nusantara University, Jakarta, Indonesia 11480.

Email: nurmaameliaas@gmail.com

Received: 12 December 2020.

Revised: 04 August 2021.

Accepted: 12 August 2021.

Published: 27 August 2021.

(c) BY-NC-ND (C) 2021 Nurma Amelia et al; published by UIKTEN. This work is licensed under the Creative Commons Attribution-NonCommercial-NoDerivs 4.0 License.

The article is published with Open Access at www.temjournal.com
Oil and gas prices are influenced by many aspects, involved by global geopolitical aspect, economic development, renewable energy and the energy consumption [2].

Let us look at the one of producer countries of the oil and gas commodity. For more than 130 years, Indonesia has been actively involved in this commodity market. This began with the discovery of the first oil in North Sumatra in 1885. Then, in 1961, Indonesia joined the Organization of Petroleum Exporting Countries (OPEC). In the end, in 2009 Indonesia suspended its membership in OPEC since the oil production continued to decline.

Finally, for a short period, Indonesia rejoined from January to November 2016. In general, during the 1996-2017 period, Indonesian crude oil production had a downward trend (see Figure 1.). Many factors affect this condition, moreover it has a great impact to government revenue from this industry [3]. The decline in Indonesian oil production is due to several factors including the decline in exploration and exploitation activities, the number of exploitation wells that have aged, and decreased number of investments.

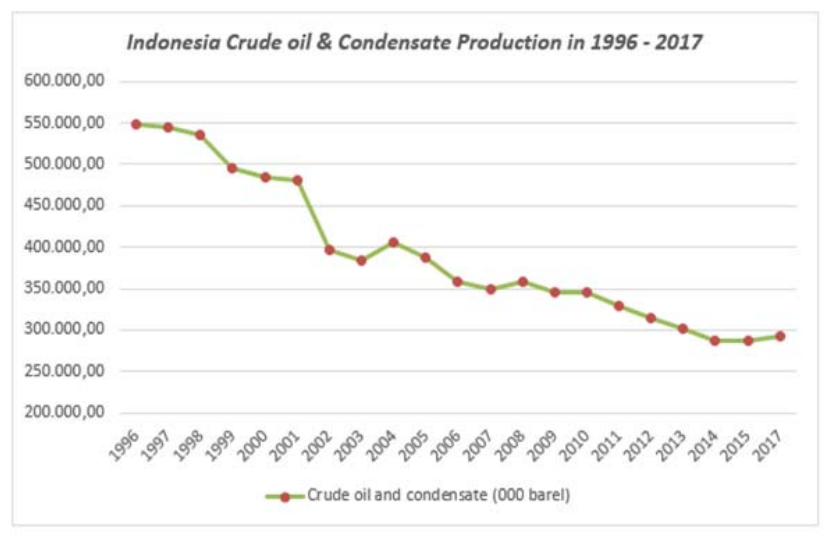

Figure 1. The amount of Indonesia's Crude Oil and Condensate Production for the period 1996-2017

Since 2003, Indonesia has experienced an oil deficit. The sharp decline of the Indonesian oil production is found in 2013 that affects the economic condition [3]. In addition to the decline in 
production, this is due to the tendency for increased domestic oil consumption. In 2019, per day, Indonesia's oil production was 1.18 million barrels with a consumption of 1.21 million barrels. The declining of the oil and gas industry productions is affected by many factors, some of them include supply and demand, pricing and regulations and also infrastructures [4].

Crude oil distribution infrastructure in Indonesia is mainly by land and sea. The number of fleets and the capacity of each mode is shown in Table 1 . As found in Indonesian government source and report [5], as of 2017, there were 8,779 land fleets and 1,537 naval fleets. This condition indicates that even the sustainability issues concerned, the oil demand is increasing. Due to the high consumption of fossil energy, the transportation of crude oil continues to increase from year to year.

Table 1. Mode and capacity of the transportation of crude oil in Indonesia

\begin{tabular}{|c|c|c|}
\hline Mode & "Total Unit & " Capacity (kL) \\
\hline Truck & 7,749 & 127,367 \\
\hline Train & 1,030 & 25,359 \\
\hline Vessel & 1,537 & $8,653,475$ \\
\hline
\end{tabular}

In Indonesia, in terms of accounting policies, operating costs are regulated in the Work Procedure Guidelines issued by the government institutions for the oil and gas sector, which aim to regulate the measurement, recognition or charging, and presentation of operating costs in upstream oil and gas operations performed by the Cooperation Contract Contractor in the Cooperation Contract. The regulations also explain the grouping of costs incurred in carrying out oil and gas upstream activities, one of which is discussing production cost accounting.

Basically, production costs include operating costs such as labour, goods, and services, one of which is used in transportation operations and oil and gas shipments [6]. The company usually carries out analysis and simulation of comparing the selection of appropriate distribution modes to be used to support its maximum operational activities. This issue is possible to solve with comparing the amount of crude oil produced and which will be distributed. The goal is to transport and distribute the crude oil optimally by considering operational costs. Solving transportation network problem for oil and gas have been developed in mathematical modelling approach as found in [7], [8], [9] while this research proposed a simulation modelling considering real world constraint of transportation route.

As can be seen in Table 2. based on the oil and gas financial statements it can be seen that operational costs are the second highest in expenditure so further investigation is needed. In 2013 and 2014 operating costs exceed fuel costs so that it can be concluded that there are anomalies in operating costs. This condition inspires this research to investigates the optimal oil transportation with considering minimizing transportation cost.

Table 2. Intermediate cost of oil and natural gas mining companies [1] (million Rupiah)

\begin{tabular}{|c|c|c|c|c|c|c|c|c|}
\hline No & Description & 2011 & 2012 & 2013 & 2014 & 2015 & Total & $\%$ \\
\hline 1 & Fuel and lubricants & $21,067,661$ & $22,265,016$ & $17,833,504$ & $16,947,136$ & $17,426,644$ & $95,539,961$ & $41 \%$ \\
\hline 2 & Operational costs & $19,488,838$ & $18,833,673$ & $18,312,941$ & $19,201,036$ & $16,333,769$ & $92,170,257$ & $39 \%$ \\
\hline 3 & Mining services & $2,579,026$ & $2,424,284$ & $6,376,241$ & $3,034,624$ & 630,857 & $15,045,032$ & $6 \%$ \\
\hline 4 & Electricity purchased & 974,831 & $1,043,403$ & $1,913,846$ & $1,111,359$ & $1,476,081$ & $6,519,520$ & $3 \%$ \\
\hline 5 & $\begin{array}{l}\text { Spare parts and } \\
\text { maintenance costs }\end{array}$ & $1,613,485$ & $1,516,676$ & $1,222,459$ & $1,453,720$ & 404,01 & $6,210,350$ & $3 \%$ \\
\hline 6 & $\begin{array}{l}\text { Rent buildings and } \\
\text { machinery }\end{array}$ & $1,095,844$ & $1,030,093$ & $1,388,402$ & $1,005,748$ & $1,030,502$ & $5,550,589$ & $2 \%$ \\
\hline 7 & Other costs & 104,743 & 42,526 & $1,286,796$ & $1,050,019$ & $2,616,191$ & $5,100,275$ & $2 \%$ \\
\hline 8 & Mining equipment & 292,764 & 788,502 & $1,117,960$ & 830,78 & 211,114 & $3,241,120$ & $1 \%$ \\
\hline 9 & $\begin{array}{l}\text { Material handling } \\
\text { costs }\end{array}$ & 780,285 & 282,684 & 521,414 & 225,335 & 341,048 & $2,150,766$ & $1 \%$ \\
\hline 10 & Others Service & 34,6 & 25,966 & 488,249 & 748,02 & 113,58 & $1,410,415$ & $1 \%$ \\
\hline 11 & $\begin{array}{l}\text { Human Resource } \\
\text { Development }\end{array}$ & 247,608 & 232,752 & 43,985 & 70,361 & 93,148 & 687,854 & $0 \%$ \\
\hline 12 & Assurance & 30,352 & 167,896 & 47,63 & 44,316 & 99,65 & 389,844 & $0 \%$ \\
\hline 13 & Consultant services & 26,74 & 26,487 & 66,604 & 25,108 & 30,846 & 175,785 & $0 \%$ \\
\hline \multirow[t]{2}{*}{14} & Office stationery & 35,335 & 45,145 & 21,932 & 12,425 & 15,413 & 130,25 & $0 \%$ \\
\hline & Total Amount & $48,372,112$ & $48,725,103$ & $50,641,963$ & $45,759,987$ & $40,822,853$ & $234,322,018$ & $100 \%$ \\
\hline
\end{tabular}


Transportation sectors need $60 \%$ of total distributed national fuel consumption [10]. This shows that the national transportation sector has a very high dependency on fuel. This condition is very unstable, especially in terms of energy security, given the declining national oil production and high oil imports. and the mobility of goods and passengers in the Indonesian transportation system is still dominated by land transportation modes.

Some studies on the crude oil distribution network have been carried out, including the following: Ref. [11] examined the optimization of the transportation network for imported crude oil to minimize logistics costs in China. Design variables include the number of tankers and allocation, selection of crude oil centre position, transportation routes, and port capacity. Ref. [12] conducted a simulation using a discrete event approach to optimize global crude oil logistics and stochastic inventory with four demand centres, namely the US, EU, Singapore, and Japan.

on the other side, optimization is also required for the transportation mode in any considerations, as found in previous research. Ref. [13] conducted a logistics system simulation for Turkey's military needs where the demand position was mobile. The military needs large amounts of fuel. The simulation model takes into account the fuel supply system through marine tankers, land tankers and pipelines, and depots. Ref. [14] examined the transportation and delivery of cargo and the capacity problems arising from the grinding process, resulting in direct and indirect costs. Authors solve the problem with dividing into several sub-fleets to work in specialized pits with simulation-based optimization methods that take into account uncertainties in mining operations. Ref. [6] examines the cross-dock centre which is an intermediate point of consolidation in the supply chain which connects suppliers with customers. The advantages of this mechanism are reduced waiting time, decreased stock levels and the economy in transportation. The article proposes a linear integer programming model to schedule incoming and outgoing trucks. This model seeks to minimize the penalty costs associated with the arrival time of the incoming truck which is implemented in CPLEX and tested in several examples provided by Renault. In other works, Ref. [15] developed a truck designation model to reduce gate congestion. The aim is to minimize trucks turning in terminals by using the Baskett Chandy Muntz Palacios (BCMP) queuing network where numerical results indicate that the proposed truck lift model can reduce truck turnover time efficiently.

Related to the transportation system, the following research proposed an approach to solve the problem. Ref. [16] tends to regulate the problems that arise in the pre-and final transport of intermodal container transportation. Trucks must be directed and scheduled to carry out several transportation requests that are subject to the origin and destination window. Also, the empty containers are considered as transportation resources and are assigned to customers and terminals to transport goods. aims to minimize the total truck operating time of all trucks used. by making formulations. Full-Truckload Pickup and Delivery Problem with Time Windows for the problem considered and the heuristic solution approach 2 stage to be completed. In other works, Ref. [17] develop a new approach in production distribution, using mathematical models for scheduling railroad production and transportation, by using two metaheuristic and by a different approach. Two different metaheuristics, genetic algorithms and simulated annealing, heuristics, and several relevant procedures were developed. With this approach, one can consider the exchange between costs incurred on both sides. To adjust the parameters of the proposed genetic algorithm, the Taguchi parameter design method is used. As a result, we can reduce the original giant combination of experiments. The proposed algorithm with the parameters set is compared simultaneously. As a result, genetic algorithms produce better solutions than simulated annealing. In addition, it checks the behaviour of the algorithm in several problem sizes, and the results show that as the size problem increases, the genetic algorithm shows better results and also maintains strong performance.

This paper proposed a new approach to optimize crude oil transfer by Trucking Services with Agent Based Modelling. This issue is necessary to improve the transportation system of the crude oil and provide an optimal solution to minimize the transportation cost. In the following, the research method, result and discussion are provided to solve the problem.

\section{Research Method}

This research discusses the process of optimizing the distribution of crude oil through land transportation using tanker trucks. The case involves an oil company in the upstream of the oil and gas industry operating in Sumatra, Indonesia. The producer utilizes land transportation involving tank trucks to transport the liquid across the supply-chain network (see Figure 2.). In the figure, the location A is the field of operational activities and oil production.

Producers use land transportation that involves tanker trucks to transport the oil through the supply chain network. Figure 2. is the production location, producing 2,500-3,100 barrels from production wells. Before being distributed, the oil is pre-processed to separate water and oil using a separator. Then be distributed to a storage tank temporary which will be 
carried to the lifting location using a tanker truck. The first tank is used to transfer oil to a tanker truck, while the other tank is necessary to process the production received from the well. Every day, the oil produced is transported by tanker truck to lifting location (Figure 3.).

At this location there are 2 storage tanks which are used as the same as in the production location, when the first tank used to transfer oil to the buyer, the other thank is intended to carry out the activity to receiving oil from the tanker truck into the tank. From this location, crude oil is distributed to refineries using pipeline.

For an illustration and a case study, Figure 4. shows two considered alternative routes to transport the crude oil from location A (production location) to location B (lifting location). At the location A, crude oil is produced every day with the amount fluctuating with an average of around 3,000 barrels/day. The oil is then stored in two tanks with a total capacity of 30,000 barrels. From Location A to B, oil is carried by $80-100$ trucks, with each truck having a capacity of $5000 \mathrm{~L}$ (30 barrels).

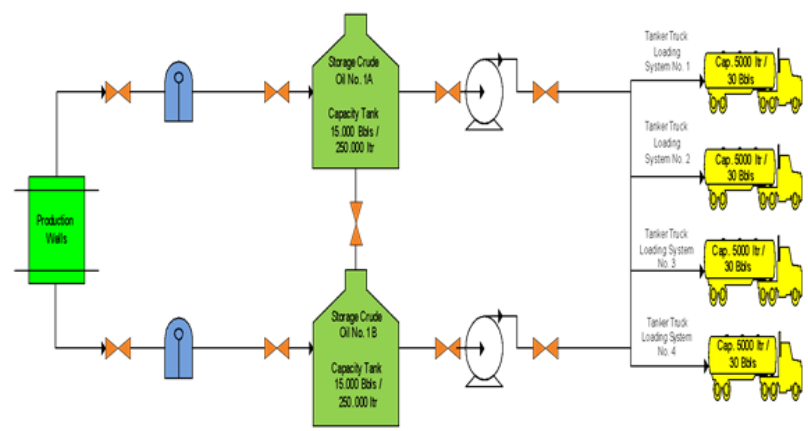

Figure 2. Production location

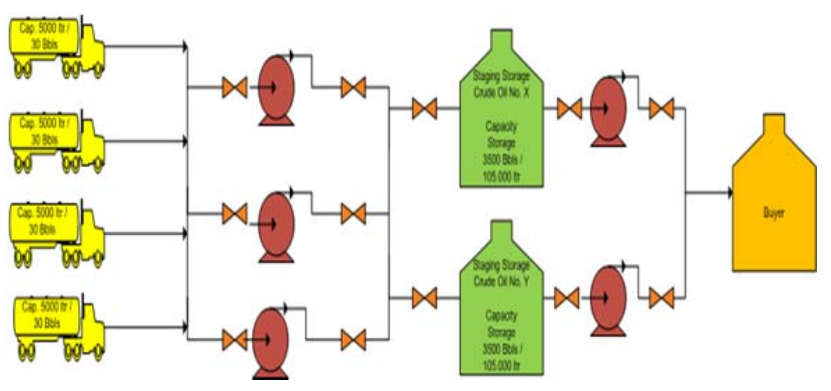

Figure 3. Lifting location

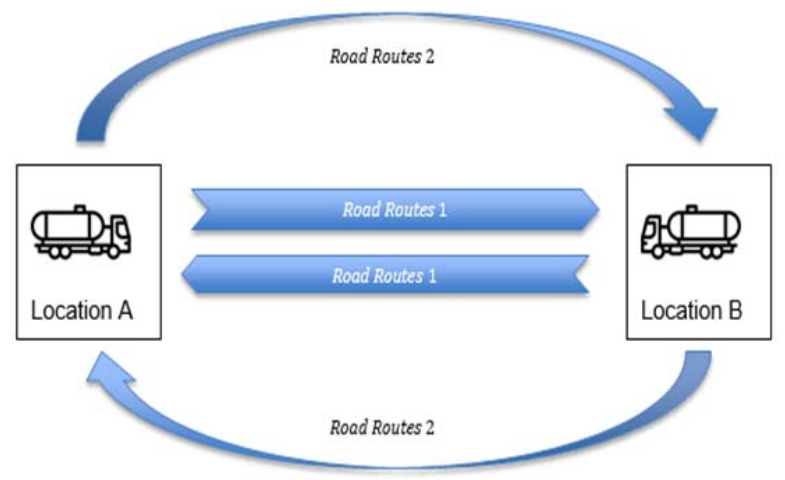

Figure 4. Two considered alternative routes for channelling the crude oil
At the location A there are four loading shelters with the loading process taking 45 minutes per truck. From Location A to B, the truck has two alternative ways in transportation. Alternative 1 has $190 \mathrm{~km}$ and takes about 7 hours. Alternative 2 is $230 \mathrm{~km}$ away with a travel time of approximately 14 hours. Travelling time from Location A to Location B is fluctuating influenced by road conditions, weather, vehicle conditions, and social conditions of the local community.

Location B also has two temporary shelters with a total capacity of 7,000 barrels. Location B has 4 units of loading and unloading facilities, namely Tanker truck unloading shelter, for the unloading process it can take around \pm 50 minutes for 4 trucks.

\section{Result and Discussion}

This study addresses the issue of the optimal number of tanker trucks for crude-oil transportation in certain circumstances and production. Considering optimal transportation in a business is necessary since it involves $60 \%$ of total cost in business [18]. Therefore, the following described the scenarios of unexpected events and production planning to design an optimal transportation.

The unexpected events include the occurrences of accidents, human negligence, natural disasters, and others during transportation and distribution. Those events cause delays in the process of sending and receiving crude oil at Location $B$. In the process of traveling to Location $\mathrm{B}$, the events make the process taking longer time since the trucks should choose a different travel route, from the shortest route with a distance of $190 \mathrm{~km}$ with 8 hours traveling time to a much longer route at the distance of $230 \mathrm{~km}$ with a travel time of 14 hours in one trip. This condition dotes a complex transportation problem to be solved.

The decision leads to a great in the terms of travel time, travel costs, and the accumulation of crude oil in existing production tanks. This condition is also affecting the volume of crude oil shipments sent from Location A to Location B in a specific time. A simulation model of two travel routes is performed by comparing the optimal number of tanker trucks for route 1 and route 2 .

The fluctuation of the amount of production depends on the condition of the production well and the effort made by the producer. To maintain the stability of the total production at the production well, it should perform a maintenance of the well every year in a schematic process [19], [20]. As an assumption, this case determines the total production in the last four years was within the range of 1,000 barrels per day and 3,500 barrels per day. 


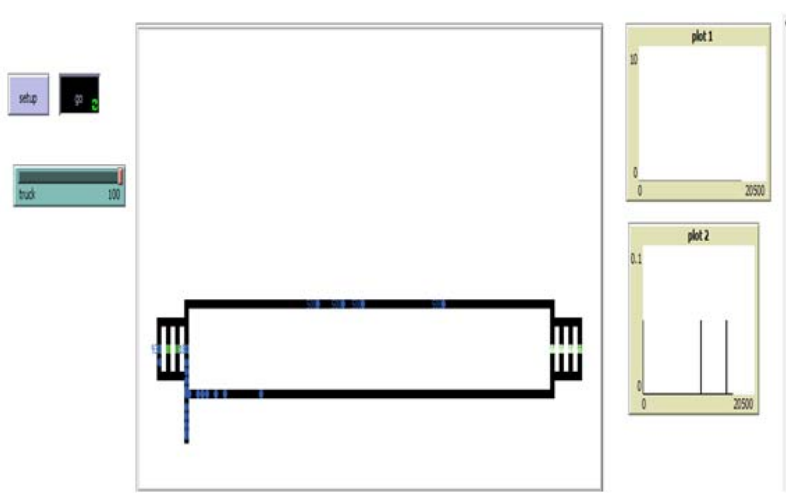

Figure 5. Simulation Modelling with Net Logo

To find an optimal solution, a simulation modelling with agent-based approach is proposed. As can be seen in the existing program simulation (see Figure 5.), the study evaluates two scenarios described previously: the first simulation is using Route 1 and the second simulation is using Route 2 . Based on the results of simulations that have been carried out using Net Logo software, we compare the results of the two options in Table 3 . and Table 4.

Table 3. The simulation results for Route 1 with a length of $190 \mathrm{~km}$ without unexpected events

\begin{tabular}{|c|c|c|c|}
\hline Year & $\begin{array}{c}\text { Average } \\
\text { Production } \\
\text { (barrel/day) }\end{array}$ & $\begin{array}{c}\text { Average } \\
\text { Lifting } \\
\text { (barrel/day) }\end{array}$ & $\begin{array}{c}\text { Optimal } \\
\text { Tank } \\
\text { Truck }\end{array}$ \\
\hline 2016 & $1,000-1,200$ & $700-1,100$ & 30 \\
\hline 2017 & $1,500-1,800$ & $1,300-1,700$ & 50 \\
\hline 2018 & $2,100-2,500$ & $1,900-2,300$ & 80 \\
\hline 2019 & $2,800-3,000$ & $2,600-3,000$ & 90 \\
\hline 2020 & $3,100-3,500$ & $2,800-3,200$ & 100 \\
\hline
\end{tabular}

Table 4. The simulation results for Route 2 with a length of $230 \mathrm{~km}$ without unexpected events

\begin{tabular}{|c|c|c|c|}
\hline Year & $\begin{array}{c}\text { Average } \\
\text { Production } \\
\text { (barrel/day) }\end{array}$ & $\begin{array}{c}\text { Average } \\
\text { Lifting } \\
\text { (barrel/day) }\end{array}$ & $\begin{array}{c}\text { Optimization } \\
\text { Total Tank } \\
\text { Truck }\end{array}$ \\
\hline 2016 & $1000-1300$ & $800-1100$ & 30 \\
\hline 2017 & $1500-1800$ & $1300-1600$ & 45 \\
\hline 2018 & $2100-2500$ & $1800-2300$ & 80 \\
\hline 2019 & $2800-3000$ & $2600-3000$ & 100 \\
\hline
\end{tabular}

As showed at the results, the simulation modelling enables to demonstrate the number of optimal trucks to operate in every year. The number of total trucks has been considered total cost of transportation and maximize the number of distributed crude-oil for customer.

Further, the transportation route 2 provided a minimum number of mode transportation than route 1 in 2017. We also find the similar condition for 2019 when at route 1 , it should operate 100 trucks while at route 2 it is only required 90 trucks. This result indicates that route 2 is the optimal route alternative to distribute the crude oil to consumers.

\section{Conclusion}

This research has succeeded to determine the optimal operating conditions of tank trucks to distribute the crude oil to customers. An agent-based model is developed to simulate the crude oil production for four years from 2016 until 2020. This research also found 2 route alternatives to distribute the crude oil for consumers. The simulation modelling using agent-based approach enables to demonstrate the optimal number of the operated trucks. This research simulates that route 2 is the best alternative route to optimize the number of trucks, distributed volume of crude oil and also the total transportation cost.

For further research, a decision-making approach is possible to apply the simulation modelling to provide a real time decision for the decision maker.

\section{References}

[1]. Direktorat Jenderal Migas. (2018). Laporan Kinerja Dirjen Migas Tahun 2018. Jakarta: Direktorat Jendral Migas.

[2]. Vătavu, S., Lobonț, O. R., Para, I., \& Pelin, A. (2018). Addressing oil price changes through business profitability in oil and gas industry in the United Kingdom. PloS one, 13(6), e0199100. https://doi.org/10.1371/JOURNAL.PONE.0199100

[3]. Daryanto, W. M., \& Nurfadilah, D. (2018). Financial performance analysis before and after the decline in oil production: Case study in Indonesian oil and gas industry. International Journal of Engineering \& Technology, 7(3.21), 10-15.

https://doi.org/10.14419/ijet.v7i3.21.17085

[4]. Purwanto, W. W., Muharam, Y., Pratama, Y. W., Hartono, D., Soedirman, H., \& Anindhito, R. (2016). Status and outlook of natural gas industry development in Indonesia. Journal of Natural Gas Science and Engineering, 29, 55-65. https://doi.org/10.1016/j.jngse.2015.12.053

[5]. ESDM. (2018). Annual Archivement of Development Report: Utilization of Natural Gas. Kementerian Energi dan Sumber Daya Mineral, 120.

Retrieved from:

https://migas.esdm.go.id/uploads/uploads/files/lapora n-tahunan/Laptah-Migas-2018---FINAL.pdf [accessed: 10 October 2020].

[6]. Serrano, C., Delorme, X., \& Dolgui, A. (2017). Scheduling of truck arrivals, truck departures and shop-floor operation in a cross-dock platform, based on trucks loading plans. International Journal of Production Economics, 194, 102-112. https://doi.org/10.1016/J.IJPE.2017.09.008

[7]. Cheng, L., \& Duran, M. A. (2004). Logistics for world-wide crude oil transportation using discrete event simulation and optimal control. Computers \& chemical engineering, 28(6-7), 897-911. https://doi.org/10.1016/J.COMPCHEMENG.2003.09. $\underline{025}$ 
[8]. van Dorp, J. R., \& Merrick, J. R. (2011). On a risk management analysis of oil spill risk using maritime transportation system simulation. Annals of Operations Research, 187(1), 249-277. https://doi.org/10.1007/S10479-009-0678-1

[9]. Latpate, R., \& Kurade, S. S. (2020). Multi-objective multi-index transportation model for crude oil using fuzzy NSGA-II. IEEE Transactions on Intelligent Transportation Systems. https://doi.org/10.1109/TITS.2020.3024693

[10]. Widyaparaga, A., Widodo, T., Handika, I., Setiawan, I. C., \& Lindasista, A. (2020). Modelling of Indonesian road transport energy sector in order to fulfill the national energy and oil reduction targets. Renewable Energy, 146, 504-518. https://doi.org/10.1016/J.RENENE.2019.06.169

[11]. Chen, J., Lu, J., \& Qi, S. (2010, August). Transportation network optimization of import crude oil in China based on minimum logistics cost. In 2010 IEEE International Conference on Emergency Management and Management Sciences (pp. 335338). IEEE.

https://doi.org/10.1109/ICEMMS.2010.5563432

[12]. Cheng, L., \& Duran, M. A. (2004). Logistics for world-wide crude oil transportation using discrete event simulation and optimal control. Computers \& chemical engineering, 28(6-7), 897-911. https://doi.org/10.1016/J.COMPCHEMENG.2003.09. $\underline{025}$

[13]. Sabuncuoglu, I., \& Hatip, A. (2005). The Turkish Army uses simulation to model and optimize its fuelsupply system. Interfaces, 35(6), 474-482. https://doi.org/10.1287/INTE.1050.0173
[14]. Ozdemir, B., \& Kumral, M. (2019). Simulationbased optimization of truck-shovel material handling systems in multi-pit surface mines. Simulation Modelling Practice and Theory, 95, 36-48. https://doi.org/10.1016/J.SIMPAT.2019.04.006

[15]. Zhang, X., Zeng, Q., \& Chen, W. (2013). Optimization model for truck appointment in container terminals. Procedia-Social and Behavioral Sciences, 96, 1938-1947. https://doi.org/10.1016/J.SBSPRO.2013.08.219

[16]. Nossack, J., \& Pesch, E. (2013). A truck scheduling problem arising in intermodal container transportation. European Journal of Operational Research, 230(3), 666-680. https://doi.org/10.1016/J.EJOR.2013.04.042

[17]. Hajiaghaei-Keshteli, M., \& Aminnayeri, M. (2014). Solving the integrated scheduling of production and rail transportation problem by Keshtel algorithm. Applied Soft Computing, 25, 184-203. https://doi.org/10.1016/J.ASOC.2014.09.034

[18]. Paiva, R. P., \& Morabito, R. (2009). An optimization model for the aggregate production planning of a Brazilian sugar and ethanol milling company. Ann Oper Res, 169, 117-130. https://doi.org/10.1007/s10479-008-0428-9

[19]. Tang, Y., Zou, Z., Jing, J., Zhang, Z., \& Xie, C. (2015). A framework for making maintenance decisions for oil and gas drilling and production equipment. Journal of natural gas science and engineering, 26, 1050-1058. https://doi.org/10.1016/J.JNGSE.2015.07.038

[20]. Shou, W., Wang, J., Wu, P., \& Wang, X. (2020). Lean management framework for improving maintenance operation: development and application in the oil and gas industry. Production Planning and Control, 1-18. https://doi.org/10.1080/09537287.2020.1744762 